\title{
Different mechanisms of two anti-anthrax protective antigen antibodies and function comparison between them
}

\author{
Siping Xiong ${ }^{1,2,3}$, Tingting Zhou ${ }^{1}$, Feng Zheng ${ }^{1}$, Xudong Liang ${ }^{4}$, Yongping Cao ${ }^{1}$, Chunhui Wang ${ }^{1}$, Zhengqin Feng ${ }^{2}$,
} Qi Tang ${ }^{2^{*}}$ and Jin Zhu ${ }^{1,2^{*}}$

\begin{abstract}
Background: Bacillus anthracis causes a highly lethal infectious disease primarily due to toxin-mediated injury. Antibiotics are no longer effective to treat the accumulation of anthrax toxin, thereby new strategies of antibody treatment are essential. Two anti- anthrax protective antigen (PA) antibodies, hmPA6 and PA21, have been reported by our lab previously.

Methods: The mechanisms of the two antibodies were elucidated by Electrophoresis, Competitive Enzyme-linked immune sorbent assay, Western blot analysis and immunoprecipitation test, and in vitro, in vivo (F344 rats) treatment test. The epitopes of the two antibodies were proved by Western blot and Enzyme-linked immune sorbent assay with different domains of PA.

Results: In this study, we compared affinity and neutralization of these two antibodies. PA21 was better in protecting cells and rats, whereas hmPA6 had higher affinity. Furthermore, the neutralization mechanisms of the two antibodies and their recognition domains of PA were studied. The results showed that hmPA6 recognized domain IV, thus PA could not bind to cell receptors. Conversely, PA21 recognized domain II, thereby limiting heptamer oligomerization of PA63 in cells.

Conclusions: Our studies elucidated the mechanisms and epitopes of hmPA6 and PA21. The present investigation can advance future use of the two antibodies in anthrax treatment or prophylaxis, and potentially as a combination treatment as the antibodies target different epitopes.
\end{abstract}

Keywords: Anthrax, Protective antigen, Lethal toxin, Neutralizing antibody, Mechanism

\section{Background}

Bacillus anthracis is a sporulating Gram-positive bacterium that can cause high morbidity and mortality, and it is also considered as a potential weapon of bioterrorism $[1,2]$. In some parts of the world, this lethal disease is still endemic principally to herbivores and also can affect other species, including humans [3]. In the past decade, some terrorists used the anthrax agents and/or their associated toxins as bioweapons. In addition, some people have been exposed to anthrax spores during

\footnotetext{
* Correspondence: qitang@njmu.edu.cn; zhujin1968@njmu.edu.cn

${ }^{2}$ Key Laboratory of Antibody Technique of Ministry of Health, Nanjing

Medical University, Nanjing 210029, China

${ }^{1}$ Epidemiological Department, Huadong Medical Institute of Biotechniques,

Nanjing 210002, China

Full list of author information is available at the end of the article
}

bioterrorism events $[3,4]$. These make it necessary to study anthrax pathogenesis, treatment, etc.

The pathogenesis of $B$. anthracis is mainly caused by anthrax toxin which is a tripartite protein complex. The three-protein toxin consist of a cellular receptors binding component, the protective antigen (PA), and two catalytic components, lethal factor (LF) and edema factor $(\mathrm{EF})[5,6]$. First, PA binds to cell surface receptors (the tumor endothelial marker 8, TEM-8; the capillary morphogenesis protein-2, CMG-2) [7, 8]. Subsequently, the amino-terminal $20-\mathrm{kDa}$ region of PA is cleaved by furin protease and released. The remaining portion of PA bound on cell surface, named PA63, forms a homoheptamer, which can bind and transduce EF/LF into cells. LF is a zinc-dependent protease specific for the

(c) The Author(s). 2019 Open Access This article is distributed under the terms of the Creative Commons Attribution 4.0 International License (http://creativecommons.org/licenses/by/4.0/), which permits unrestricted use, distribution, and reproduction in any medium, provided you give appropriate credit to the original author(s) and the source, provide a link to the Creative Commons license, and indicate if changes were made. The Creative Commons Public Domain Dedication waiver (http://creativecommons.org/publicdomain/zero/1.0/) applies to the data made available in this article, unless otherwise stated. 
mitogen-activated protein kinase family, and EF is a calmodulin-activated adenylyl cyclase [9-11]. Therefore, LF or EF could induce cells lethal or edema effect separately.

Although, at the early stages of anthrax, antibiotics can be effective for bacterial elimination [12, 13]. With the accumulation of anthrax toxin, antibiotics are no longer effective and the disease is often lethal despite treatment [14]. Thus, at later stages of anthrax, other countermeasures are essential. Therefore, several studies, mainly focus on PA, LF, or capsular antigen, have been searching for various therapeutic strategies [15-17]. As such, the most promising approach employed anti-toxin antibody treatment to generate a state of immediate passive immunity.

In our previous studies, we developed two anti-PA antibodies that showed good function in neutralizing lethal toxin [18, 19]. Therefore, we studied the neutralization mechanisms of these two antibodies. According to the pathogenesis, PA is divided into four domains: domain I (residues 1-258) contains the furin proteolysis site, and the furin proteolysis site make domain I to domain I a and domain I b (domain I b explores the LF/EF binding site); domain II (residues 259-487) and domain III (residues 488-595) are involved in heptamer and pore formation; domain IV (residues 596-735) binds to the cellular anthrax toxin receptors [20]. Here, we compared these two antibodies on aspects of affinity and protective function. Further, we reported their neutralization mechanisms based on the pathogenesis and characterize which domain they recognize.

\section{Methods}

\section{Affinity and neutralization assay}

The affinity, in vitro and in vivo neutralization assay of hmPA6 and PA21 were reported by our lab previously $[18,19]$. Briefly, the affinity was detected by Biacore $\mathrm{X} 100$. The in vitro neutralization assay was performed with J774A.1 cells which were incubated with lethal toxin and antibodies. The in vivo neutralization assay was performed with F344 rats which were injected with lethal toxin and antibodies in different time points via tail vein.

\section{Interference with LF binding Competitive ELISA}

The enzyme immunoassay plates were coated with $100 \mu \mathrm{L}$ PA63 antigen at a concentration of $2 \mu \mathrm{g} / \mathrm{mL}$ overnight at $4{ }^{\circ} \mathrm{C}$. The PA63 was diluted in $50 \mathrm{mM}$ sodium carbonate buffer (pH 9.6). After blocking, serial two-fold dilutions of $\mathrm{LF}$ and $0.125 \mu \mathrm{g} / \mathrm{mL}$ PA21 or $0.0625 \mu \mathrm{g} / \mathrm{mL}$ hmPA6 were added to the wells ( 3 wells for each concentration) with $2 \mathrm{~h}$ incubation at $37^{\circ} \mathrm{C}$. Then the experiment was done as previous described ELISA [19]. The experiment was done for three independent times.

\section{Co-immunoprecipitation (co-IP)}

A mixture of PA63 and LF were incubated with different amounts of hmPA 6 at $4{ }^{\circ} \mathrm{C}$ and rotated for $3 \mathrm{~h}$. Next, $50 \mu \mathrm{L}$ protein-A Sepharose (Invitrogen, USA) was added and incubated at $4{ }^{\circ} \mathrm{C}$. The immune complexes that formed were washed three times with PBST. Subsequently, $50 \mu \mathrm{L}$ elution buffer was added to separate these antibody-antigen complexes from protein-A Sepharose. As a negative control, LF was incubated with hmPA6 alone. The protein complexes were isolated by running two 10\% SDS-PAGE gels; and they were transferred onto a nitrocellulose membrane. The nitrocellulose membranes were blocked at $4{ }^{\circ} \mathrm{C}$ overnight, one incubated with 1:5000 diluted rabbit polyclonal anti-PA antibody (Pierce, USA) and the other incubated with anti-LF antibody for $1 \mathrm{~h}$ at RT, washed with PBST 3 times, and reacted with 1:4000 diluted goat anti-rabbit IgG-HRP conjugate (Sigma,USA) for an additional $30 \mathrm{~min}$ at room temperature. The membrane was washed 3 times with PBST, and the hybridization signal was detected using ECL Western Blot substrate (Millipore, USA). Similar procedures were used for PA21 detection.

\section{Neutralization assay of cell and animal}

The assay was performed as previously described [19], with slight modification that the antibody, PA and LF were treated separately. In cell neutralizing assay, PA was added $3 \mathrm{~h}$ before the mixture of LF and different amount of antibody. The experiment was performed independently 3 times.

F344 rats weighing between 130and $160 \mathrm{~g}$ were ordered from Charles river Company (Beijing, China). 24 female rats were divided into 4 groups, with 6 rats in each group. PA was administered before or after the mixture of LF and antibody. The alive rats in each group will be record. The remaining alive rats will be euthanized by carbon dioxide. All experiments involving animals were performed in accordance with the protocols approved by the Animal Care and Use Committee of the Nanjing Medical University, China.

\section{Inhibition of PA binding to receptor-W-Western blot}

The murine macrophage J774A.1 cells owned by our lab were cultured in 24-well plates overnight. One microgram PA83 and increasing amounts of antibody were added to wells. After $3 \mathrm{~h}$ incubation, the wells were washed with PBS three times. For cell lysate, RIPA (Radio Immunoprecipitation Assay) lysis buffer (Promab) was added to cells and incubated for $30 \mathrm{~min}$ on ice. The cell lysates were isolated by $10 \%$ SDS-PAGE. The following western blot experiment was done as 
previously described [18]. The PA binding to cells was detected, and GAPDH served as a control.

\section{Interference with Furin cleavage}

Briefly, $25 \mu \mathrm{g}$ PA was incubated in $100 \mu \mathrm{L}$ PBS with 1-unit Furin (Sigma) at RT for different durations. According to this, $25 \mu \mathrm{g}$ PA and different amounts of antibody were incubated in $100 \mu \mathrm{L} \mathrm{PBS}$ with 1-unit Furin at RT for $6 \mathrm{~h}$. Following, the mixture was isolated by running on $10 \%$ SDS-PAGE gels and stained with Coomassie Blue.

\section{Mapping of MAb binding to PA}

The individual protein domains of $\mathrm{PA}$, which are composed of amino acids 1 to 258 (domain I), 596 to 735 (domain IV), 164 to 487 (domainIb, II), and 164 to 595 (domain Ib, II and III), were cloned into Escherichia coli strain BL21, expressed, and purified as described previously [21]. Each recombinant domain was resolved by SDSPAGE and transferred to nitrocellulose for immunoblotting. The blots were blocked with $5 \%$ nonfat dry milk in $10 \mathrm{mM}$ Tris-buffered saline (PBS), $\mathrm{pH} 7.3$ and then probed with each monoclonal antibody at an appropriate dilution. The remaining steps was performed as Western blot section described. The domain 4 was also performed by ELISA. The procedure was conducted as described before.

\section{Statistical analysis of survival data}

Kaplan Meier analysis was used for evaluation of survival. Survival data were analyzed using the GraphPad Prism version 5 statistical analysis software (San Diego, CA). A two-tailed log rank test was used to determine the statistical significance of differences between groups. A $P$ value of $<0.05$ was considered statistically significant.

Other values are presented as Means \pm SEM. One-way or two-way analysis of variance followed by Bonferroni Significant Difference test was used to analyze the differences within groups where appropriate. Significance level was set at $p<0.05$.

\section{Results}

Affinity and neutralization

The affinity and neutralization assays were reported by our lab previously. Here, we compared these two antibodies, as shown in Fig. 1. Briefly, the equilibrium dissociation constants $(\mathrm{Kd})$ of PA21 and hmPA6 were determined by BiaCoreX100 analysis. The affinity of hmPA6 and PA21 were $1.438 \times 10-10 \mathrm{M}$ and $1.003 \times$ 10-9 M (Fig. 1a), respectively. J774A.1 cells were used to assess the ability of hmPA6 and PA21 to protect against LeTx. The antibody, PA83 and different concentration of LF were added to cells simultaneously. The cell viability indicated that the PA21 and hmPA6 could completely neutralize LeTx. At $10 \mu \mathrm{g} / \mathrm{mL}$ LF and $0.1 \mu \mathrm{g} / \mathrm{mL}$

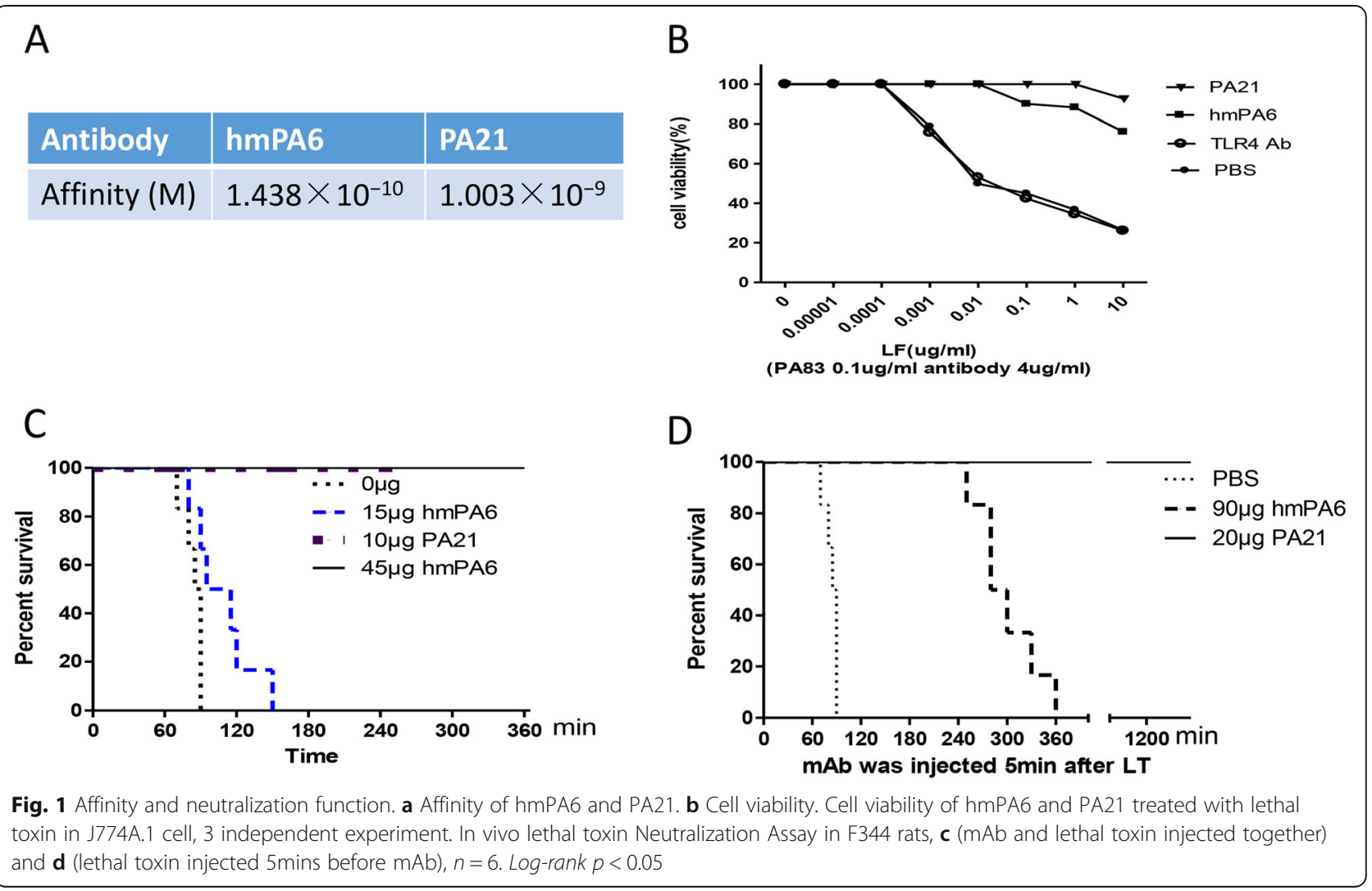


PA83, $>80 \%$ of the hmPA6-treated cells and $>90 \%$ of the PA21-treated cells remained viable, while only $26 \%$ of the control IgG antibody-treated cells remained viable (Fig. 1b).

The in vivo neutralization test was performed on F344 rats. Antibody was injected via the tail vein simultaneously, before or after LeTx injection. In the simultaneously treated groups, all rats survived using $10 \mu \mathrm{g}$ PA21 or $45 \mu \mathrm{g} \mathrm{hmPA6}$ (Fig. 1c). In the antibody injected $5 \mathrm{~min}$ after LeTx groups, all rats survived using $20 \mu \mathrm{g}$ PA21, while rats treated with hmPA6 did not (Fig. 1d).

\section{Inhibition of LF binding to PA63 Competitive ELISA}

The competitive ELISA was performed with LF, antibodies and PA63.The PA63 was coated to 96-wellELISA plate in a concentration of $2 \mu \mathrm{g} / \mathrm{mL}$. However, the OD450 of hmPA6 and PA21 was nearly identical, despite the increased concentration of LF (Fig. 2a).

\section{Co-IP assay}

The LF could be pulled down by hmPA6 and PA21 in the presence of PA63, while antibody alone could not pull down LF. Moreover, the amount of detected LF was positively correlated with detected PA63. Further, the hmPA6 and PA21 were displayed the same result (Fig. 2b).

\section{Neutralizing assay}

When the antibody was added $3 \mathrm{~h}$ after PA, even the antibody reached $8 \mu \mathrm{g} / \mathrm{mL}$, the cells were not protected (Fig. 2c). Moreover, in rats test, the antibody could not protect rats when it injected after PA (Fig. 2d).

\section{Inteference of PA binding to cell receptor}

Cell-bound PA83 (mostly cleaved to PA63) could be detected by anti-PA antibody. Briefly, $1 \mu \mathrm{g}$ PA83 and different amounts of antibodies were added to J774A.1 cells. The cells incubated with PA83 alone served as a positive control, and non-treated cells were the negative control. The detected PA83 and PA63 displayed none significant difference among the different groups of increased PA21; however, the detected PA83 and PA63 were significantly decreased among the different groups of increased hmPA6 (Fig. 3).

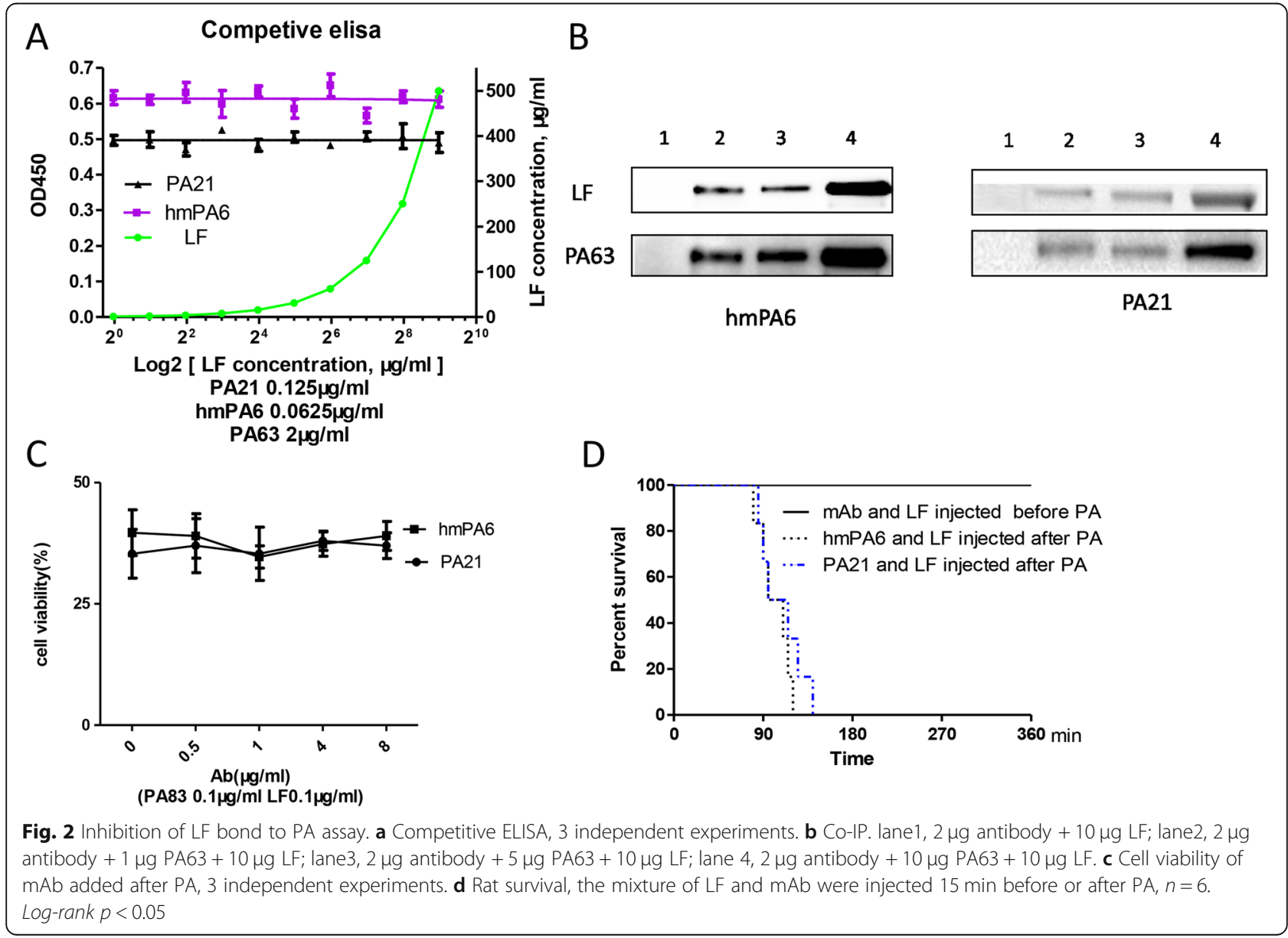




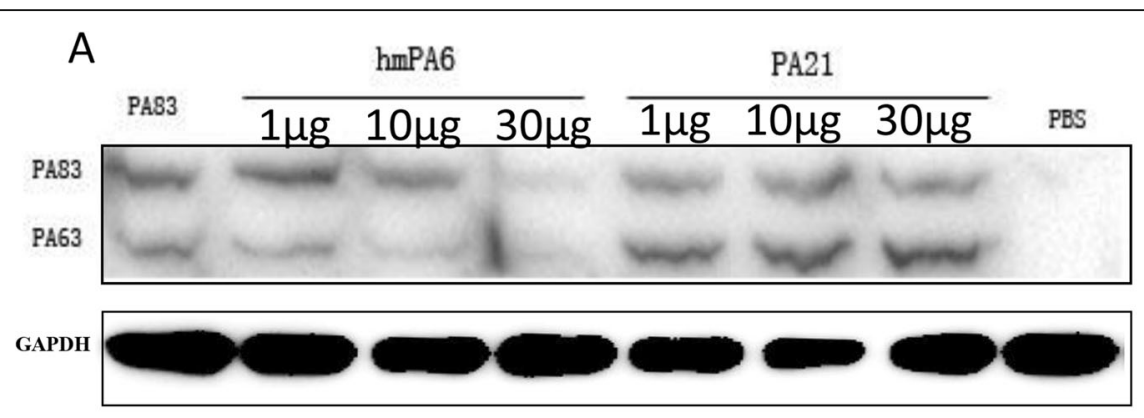

B

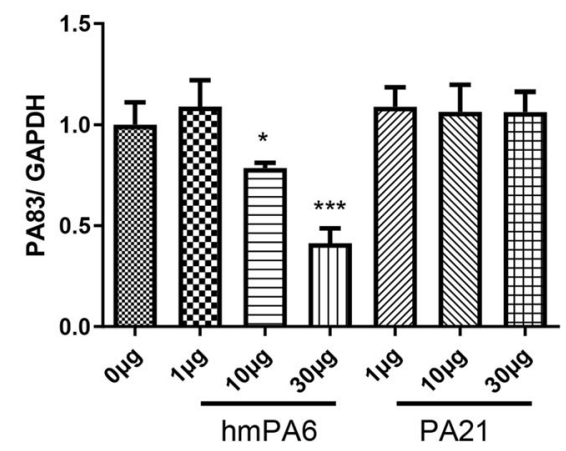

C

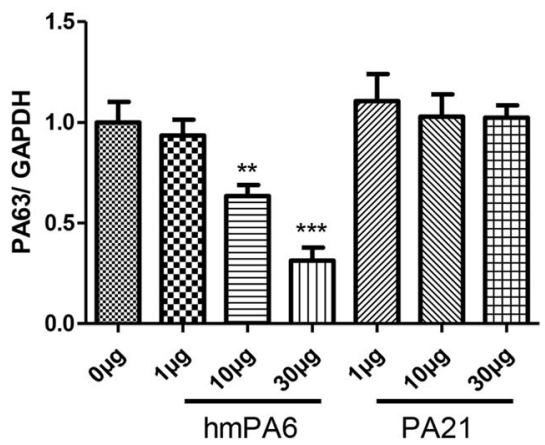

Fig. 3 Inhibition of PA bond to receptors assay. a Western Blot. b\&c Relative PA83 \& PA63 intensity. $n=4,{ }^{*} P<0.05$ vs $0 \mu \mathrm{g}$ group; ${ }^{* * *} P<0.001$ vs $0 \mu \mathrm{g}$ group

\section{Prevention of PA cleavage by Furin}

Furin was used to cleave PA83, the SDS-PAGE showed that when the cleaved time reached $6 \mathrm{~h}$, it could cleave most PA83 (Fig. 4a and b). Different amounts of antibody were added to the mixture, and incubated for $6 \mathrm{~h}$ at room temperature. With the increased antibody, the amount of cleaved PA83 showed none significant difference in both antibodies (Fig. 4c and d).

\section{Recognition of different domains of PA}

The domains of PA were constructed and expressed for western blot and ELISA. The hmPA6 could detect domain IV, however, it could not recognize protein of domainIb, IIand III (Fig. 5a and b). Moreover, hmPA6 recognized domain IVin a dose-dependent manner (Fig. 5e). Further, PA21 could detect proteins of domainIb, Iland protein of domain Ib, IIand III, however, it could not recognize domain IVand domainIalone (Fig. 5c).

\section{Discussion}

In previous study, we constructed two effective anti-PA antibodies, PA21 and hmPA6. However, we did not elucidate their recognition epitope and their mechanism of neutralizing lethal toxin. Here, we compared these two antibodies and conducted an in-depth investigation to illuminate the mechanisms of their protective effects.
First, PA21 and hmPA6 could recognize PA with an affinity of $1.003 \mathrm{nM}$ and $0.14 \mathrm{nM}$ separately. They both had high affinity, yet, hmPA6 was better than PA21. Second, both PA21 and hmPA6 could neutralize lethal toxin in vitro. However, at an antibody concentration of $4 \mu \mathrm{g} / \mathrm{mL}$, PA21 protected all cells at $1 \mu \mathrm{g} / \mathrm{mL} \mathrm{LF}$ and $0.1 \mu \mathrm{g} / \mathrm{mL}$ PA83, while hmPA6 only protected $90 \%$ cells. Finally, the in vivo test showed the similar results. PA21 could protect all F344 rats alive at a concentration of $0.067 \mathrm{mg} / \mathrm{kg}(10 \mu \mathrm{g}$ per rat), while hmPA6 required a concentration of $0.3 \mathrm{mg} / \mathrm{kg}(45 \mu \mathrm{g}$ per rat). In all, although both PA21 and hmPA6 had high affinity and well neutralization function, the affinity and the protective effects were not positively correlated. PA21 was better in protecting cells and rats, while hmPA6 had higher affinity. As a result, we investigated the mechanism of the two antibodies.

According to previous reports, we studied the mechanism in the following aspects: inhibition of PA binding to cell receptors, interference with PA proteolytically cleavage by furin protease, inhibition of the heptamer assembly of the remaining PA63 on the cells, and interference with the PA63 heptamer combined LF/EF [22, 23]. Experiments were conducted to explicate whether both the two antibodies interfered with LF bond to PA63, such as competitive ELISA, Co-IP, etc. The competitive ELISA showed that PA21 (or hmPA6) and LF were combined 

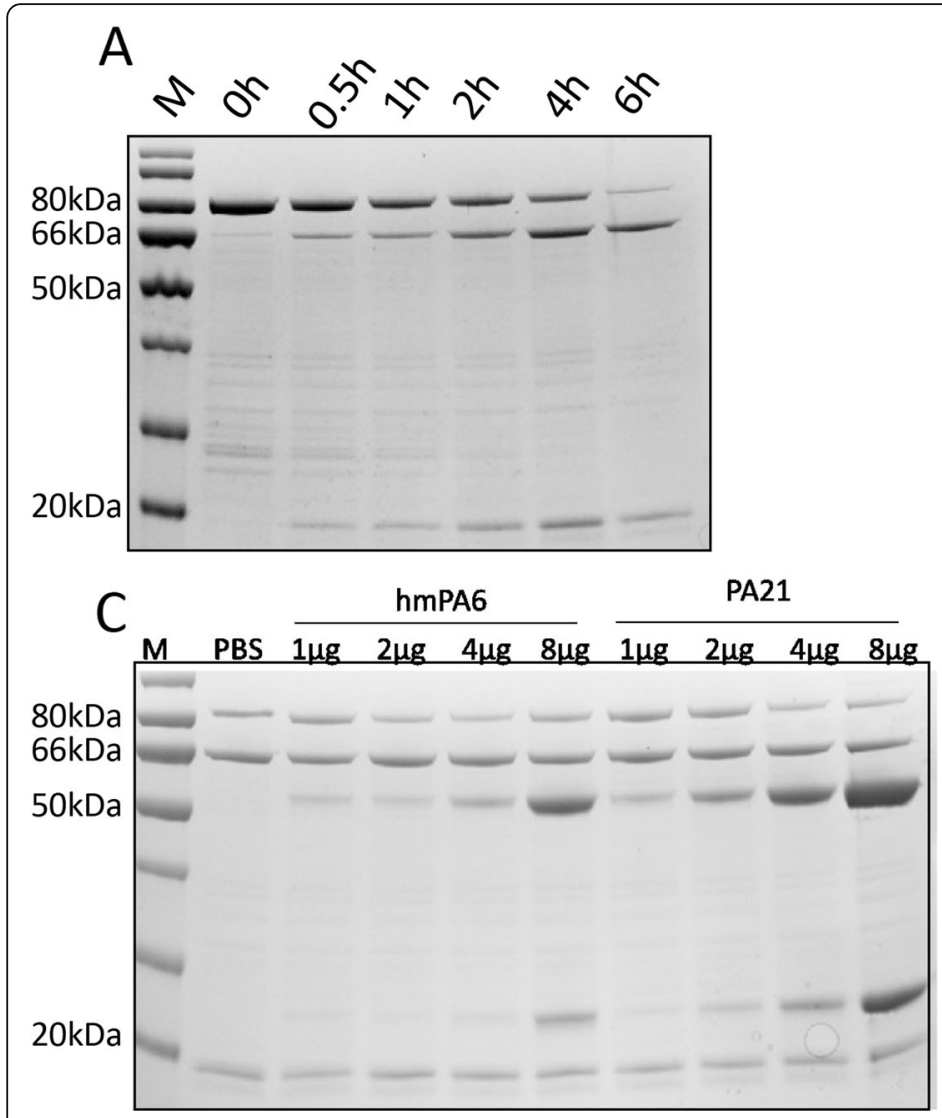

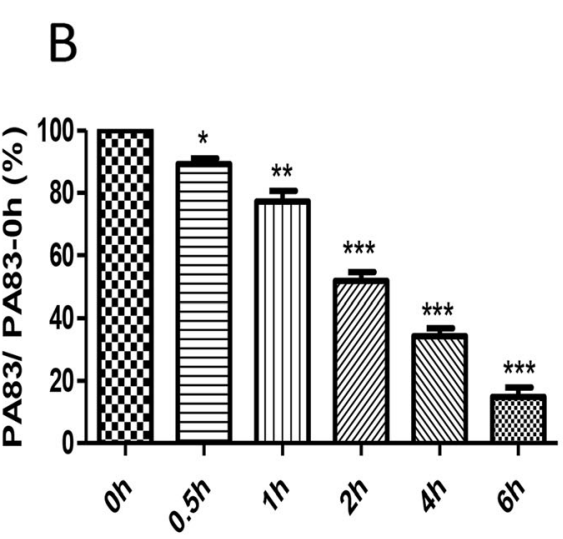

D

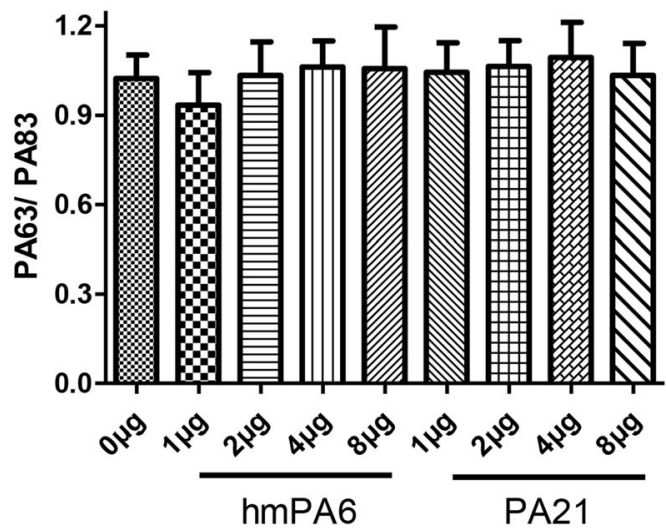

Fig. 4 Inhibition of Furin cleaving PA test. $\mathbf{a} \& \mathbf{b}$ SDS-PAGE displays cleaved PA83 by Furin in different time. $n=4 \mathbf{c} \& \mathbf{d}$ SDS-PAGE displays cleaved PA83 in different amount of mAb incubated with $25 \mu \mathrm{g}$ PA and 1 unit Furin. $n=4 * P<0.05$ vs 0 h group; *** 0.001 vs 0 h group

with PA63 separately, they had no competitive relation with PA63. Co-IP, cells and rats' protective tests displayed that PA21 (or hmPA6) could not inhibit LF binding to PA63. Consequently, we added PA and different amounts of PA21 (or hmPA6) into J774A.1 cells. After a $3 \mathrm{~h}$ incubation, we detected the PA (or PA63) binding to cell receptors. We found that PA21 had no effect on PA binding to cell receptors. However, the detected PA83 and PA63 were decreased among the different groups of increased hmPA6. Consistent with these findings, the hmPA6 cell western blot results were similar to the IHC of the lung tissue mentioned in our previous study [19]. Therefore, hmPA6 must inhibit PA binding to cell receptors. Next, we incubated furin protease, PA and different amounts of PA21 (or hmPA6) together. These two antibodies could not interfere PA cleaving to PA63 and PA20. By these experiments, we concluded that hmPA6 inhibited PA binding to cell receptors. Further we speculated that PA21 inhibited PA63 assembling to heptamer.
Furthermore, we reconstructed PA into different fragments: fragment containing only domain IV; fragment containing only domainI; fragment containing domain Ib, II and III; and fragment containing domain Ib and II. The western blot and ELISA experiments revealed that hmPA6 recognized domain IV, and PA21 recognized domain II. Several reports have already demonstrated that domain II and domain III are involved in heptamer and pore formation, while domain IV binds to the cellular anthrax toxin receptors [24-27]. Therefore, these epitope results were consistent with our mechanism results. In summary, hmPA6 recognized domain IV, thus domain IV of PA could not bind to cell receptors; PA21 recognized domain II (or domain II and III), thereby limiting oligomerization of PA63 on cells. The different mechanisms of the two antibodies caused different protective effects. PA21 showed better protective effects, as one molecular PA21 could inhibit seven or more molecular PA63 oligomerized to heptamer/octamer. However, one molecular hmPA6 perhaps only could inhibit one molecular PA bond to cell receptors. 


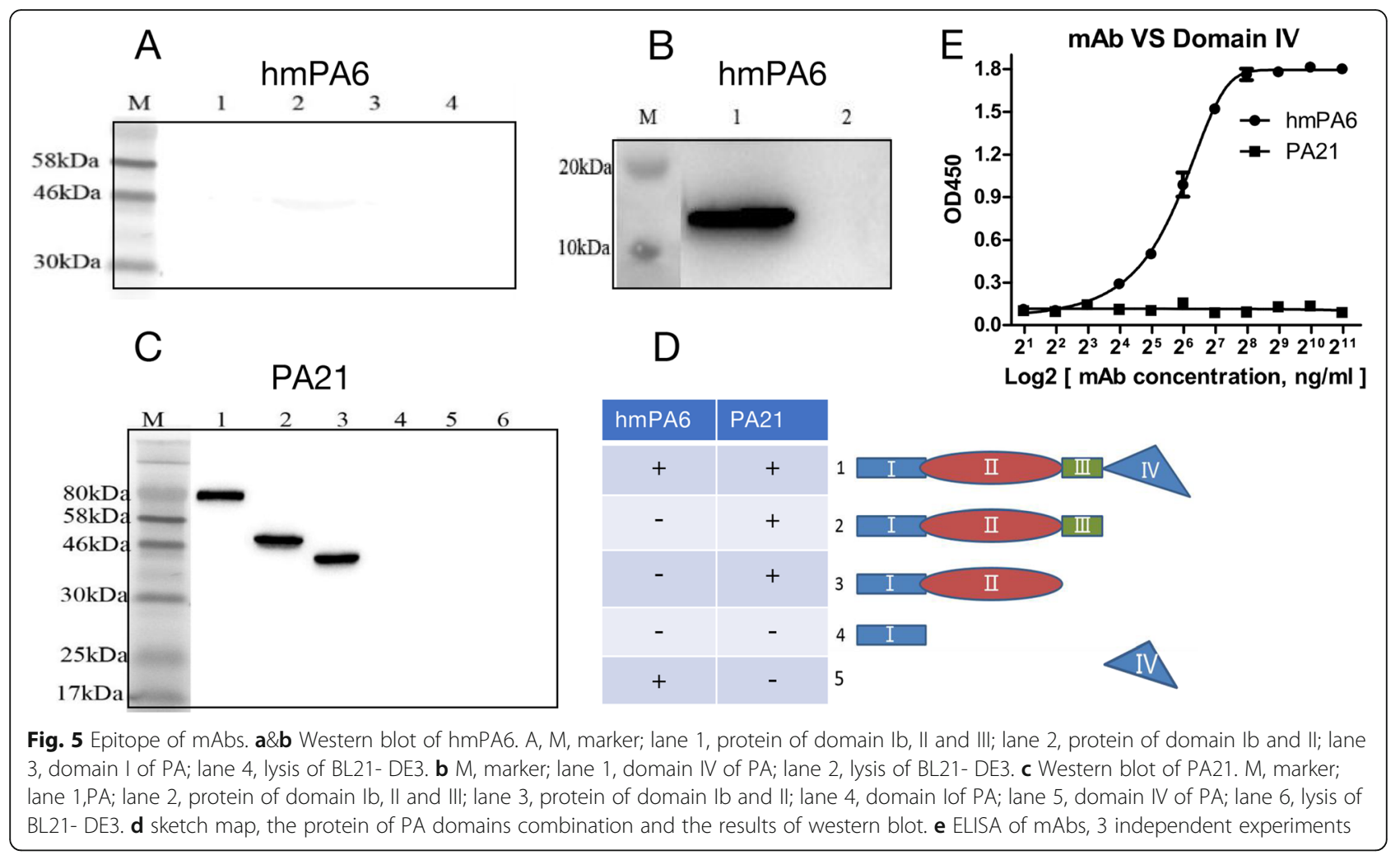

\section{Conclusions}

In this study, we first compared the affinity and neutralization function of hmPA6 and PA21. Further, we investigated the protective mechanisms of hmPA6 and PA21. Moreover, we characterized the domains of PA, which the two antibodies could recognize. We found that hmPA6 recognized domain IV, thus PA could not bind to cell receptors; and PA21 recognized domain II, thereby limiting heptamer oligomerization of PA63 in cells. The present investigation makes the two antibodies use in anthrax treatment or prophylaxis in the future clinical test more closely. Furthermore, they targeted on different epitopes indicate that they can used together.

\section{Abbreviations}

EF: Edema factor; ELISA: Enzyme-linked immunosorbent assay; LF: Lethal factor; PA: Protective antigen; PBS: Phosphate buffer saline; SDS-

PAGE: Sodium dodecyl sulphate Polyacrylamide gel electrophoresis

\section{Acknowledgements}

Not applicable.

\section{Authors' contributions}

$X S, Z T$ and ZF performed the experiments. XS, LX and CY analyzed the data. WC and FZ participated in its design and revising the manuscript. TQ and ZJ conceived of the study, participated in its design, and coordination. All authors have read and approved the final manuscript.

\section{Funding}

This work is supported by the National Science and Technology Key Project on Major Infectious Diseases (2017ZX10303401, BWS17J034) for analysis; the
National Natural Science Foundation (No. 31170884) for designing the study, the Science Fund of Jiangsu Province, China (No. BE2018617) for interpretation the study.

\section{Availability of data and materials}

The datasets used and analyzed during the current study are available from corresponding author upon request.

\section{Ethics approval and consent to participate}

All experiments involving animals were performed in accordance with the protocols approved by the Animal Care and Use Committee of the Nanjing Medical University, China.

\section{Consent for publication}

Not applicable.

\section{Competing interests}

The authors declare that they have no competing interests.

\section{Author details}

${ }^{1}$ Epidemiological Department, Huadong Medical Institute of Biotechniques, Nanjing 210002, China. ${ }^{2}$ Key Laboratory of Antibody Technique of Ministry of Health, Nanjing Medical University, Nanjing 210029, China. ${ }^{3}$ Department of Pathology, The Eighth Affiliated Hospital of Sun Yat-sen University, Shenzhen 518033, Guangdong, China. ${ }^{4}$ National Institute for Communicable Disease Control and Prevention, Chinese Center for Disease Control and Prevention, Beijing 102206, China.

Received: 14 July 2019 Accepted: 24 September 2019

Published online: 07 November 2019

\section{References}

1. Simonsen KA, Chatterjee K. Anthrax. In: StatPearls. FL: Treasure Island; 2019.

2. Alqurashi AM. Anthrax threat: a review of clinical and diagnostic measures. Egypt Soc Parasitol. 2013;43(1):147-66.

3. Goel AK. Anthrax: a disease of biowarfare and public health importance. World J Clin Cases. 2015;3(1):20-33. 
4. Steelfisher GK, Blendon RJ, Brule AS, Ben-Porath EN, Ross LJ, Atkins BM Public response to an anthrax attack: a multiethnic perspective. Biosecur Bioterror. 2012;10(4):401-11.

5. Golden HB, Watson LE, Lal H, Verma SK, Foster DM, Kuo SR, Sharma A Frankel A, Dostal DE. Anthrax toxin: pathologic effects on the cardiovascular system. Front Biosci (Landmark Ed). 2009;14:2335-57.

6. Golden HB, Watson LE, Nizamutdinov D, Feng H, Gerilechaogetu F, Lal H, Verma SK, Mukhopadhyay S, Foster DM, Dillmann WH, et al. Anthrax lethal toxin induces acute diastolic dysfunction in rats through disruption of the phospholamban signaling network. Int J Cardiol. 2013;168(4):3884-95.

7. Castanon I, Abrami L, Holtzer L, Heisenberg CP, van der Goot FG, GonzalezGaitan M. Anthrax toxin receptor 2a controls mitotic spindle positioning. Nat Cell Biol. 2013;15(1):28-39.

8. Reeves CV, Dufraine J, Young JA, Kitajewski J. Anthrax toxin receptor 2 is expressed in murine and tumor vasculature and functions in endothelial proliferation and morphogenesis. Oncogene. 2010;29(6):789-801.

9. Maddugoda MP, Stefani C, Gonzalez-Rodriguez D, Saarikangas J, Torrino S, Janel S, Munro P, Doye A, Prodon F, Aurrand-Lions M, et al. CAMP signaling by anthrax edema toxin induces transendothelial cell tunnels, which are resealed by MIM via Arp2/3-driven actin polymerization. Cell Host Microbe. 2011:10(5):464-74.

10. Al-Dimassi S, Salloum G, Saykali B, Khoury O, Liu S, Leppla SH, Abi-Habib R, El-Sibai M. Targeting the MAP kinase pathway in astrocytoma cells using a recombinant anthrax lethal toxin as a way to inhibit cell motility and invasion. Int J Oncol. 2016;48(5):1913-20.

11. Bhatnagar R, Batra S. Anthrax toxin. Crit Rev Microbiol. 2001;27(3):167-200.

12. Jang KH, Nam SJ, Locke JB, Kauffman CA, Beatty DS, Paul LA, Fenical W. Anthracimycin, a potent anthrax antibiotic from a marine-derived actinomycete. Angew Chem Int Ed Engl. 2013;52(30):7822-4.

13. Gill IJ. Antibiotic therapy in the control of an outbreak of anthrax in dairy cows. Aust Vet J. 1982;58(5):214-5.

14. Kayabas U, Karahocagil MK, Ozkurt Z, Metan G, Parlak E, Bayindir Y, Kalkan A, Akdeniz H, Parlak M, Simpson AJ, et al. Naturally occurring cutaneous anthrax: antibiotic treatment and outcome. Chemotherapy. 2012;58(1):34-43.

15. Klinman DM, Yamamoto M, Tross D, Tomaru K. Anthrax prevention and treatment: utility of therapy combining antibiotic plus vaccine. Expert Opin Biol Ther. 2009;9(12):1477-86

16. Migone TS, Bolmer S, Zhong J, Corey A, Vasconcelos D, Buccellato M, Meister G. Added benefit of raxibacumab to antibiotic treatment of inhalational anthrax. Antimicrob Agents Chemother. 2015;59(2):1145-51.

17. Beierlein JM, Anderson AC. New developments in vaccines, inhibitors of anthrax toxins, and antibiotic therapeutics for bacillus anthracis. Curr Med Chem. 2011;18(33):5083-94

18. Tang Q, Xiong S, Liang X, Kuai X, Wang Y, Wang C, Feng Z, Zhu J. Human monoclonal anti-protective antigen antibody for the low-dose post-exposure prophylaxis and treatment of Anthrax. BMC Infect Dis. 2018;18(1):640

19. Xiong S, Tang Q, Liang X, Zhou T, Yang J, Liu P, Chen Y, Wang C, Feng Z, Zhu J. A novel chimeric anti-PA neutralizing antibody for Postexposure prophylaxis and treatment of Anthrax. Sci Rep. 2015;5:11776.

20. Krantz BA, Melnyk RA, Zhang S, Juris SJ, Lacy DB, Wu Z, Finkelstein A, Collier RJ. A phenylalanine clamp catalyzes protein translocation through the anthrax toxin pore. Science. 2005;309(5735):777-81

21. Hernandez-Torres F, Pedrajas JR, Aranega AE, Navarro F. Expression in bacteria of small and specific protein domains of two transcription factor isoforms, purification and monospecific polyclonal antibodies generation, by a two-step affinity chromatography procedure. Protein Expr Purif. 2008;60(2): $151-6$.

22. Feld GK, Kintzer AF, Tang II, Thoren KL, Krantz BA. Domain flexibility modulates the heterogeneous assembly mechanism of anthrax toxin protective antigen. J Mol Biol. 2012;415(1):159-74.

23. Mechaly A, Levy H, Epstein E, Rosenfeld R, Marcus H, Ben-Arie E, Shafferman A, Ordentlich A, Mazor O. A novel mechanism for antibody-based anthrax toxin neutralization: inhibition of prepore-to-pore conversion. J Biol Chem. 2012;287(39):32665-73.

24. Williams AS, Lovell S, Anbanandam A, El-Chami R, Bann JG. Domain 4 of the anthrax protective antigen maintains structure and binding to the host receptor CMG2 at low pH. Protein Sci. 2009;18(11):2277-86.

25. Varughese M, Teixeira AV, Liu S, Leppla SH. Identification of a receptorbinding region within domain 4 of the protective antigen component of anthrax toxin. Infect Immun. 1999:67(4):1860-5.
26. Go MY, Kim S, Partridge AW, Melnyk RA, Rath A, Deber CM, Mogridge J. Self-association of the transmembrane domain of an anthrax toxin receptor. J Mol Biol. 2006;360(1):145-56.

27. Mogridge J, Mourez M, Collier RJ. Involvement of domain 3 in oligomerization by the protective antigen moiety of anthrax toxin. J Bacteriol. 2001;183(6):2111-6.

\section{Publisher's Note}

Springer Nature remains neutral with regard to jurisdictional claims in published maps and institutional affiliations.
Ready to submit your research? Choose BMC and benefit from:

- fast, convenient online submission

- thorough peer review by experienced researchers in your field

- rapid publication on acceptance

- support for research data, including large and complex data types

- gold Open Access which fosters wider collaboration and increased citations

- maximum visibility for your research: over $100 \mathrm{M}$ website views per year

At BMC, research is always in progress.

Learn more biomedcentral.com/submissions 